\title{
Physicochemical characterisation, and antioxidant properties of the seeds and oils of ginger (Zingiber Officinale) and garlic (Allium Sativum)
}

\author{
Aletor Oluwatoyin \\ Department of Chemistry, The Federal University of Technology, P.M.B 704 Akure, Nigeria

\section{Email address:} \\ toyinaletor@yahoo.com
}

\section{To cite this article:}

Aletor Oluwatoyin. Physicochemical Characterisation, and Antioxidant Properties of the Seeds and Oils of Ginger (Zingiber Officinale) and Garlic (Allium Sativum). Science Journal of Chemistry. Vol. 2, No. 6, 2014, pp. 44-50. doi: 10.11648/j.sjc.20140206.11

\begin{abstract}
Ginger (Zingiber officinale) and garlic (Allium sativum) were characterized with respect to their proximate composition, energy value, mineral content, anti-nutrient constituents, functional and antioxidants properties. Their seed oils were also extracted and characterised with respect to their physicochemical properties and fatty acid profiles. The crude protein $(\mathrm{CP})$, crude fibre $(\mathrm{CF})$, ether extract $(\mathrm{EE})$, ash and gross energy of ginger averaged 7.8, 6.2, 11.0, 9.0 g/100gDM and 385.6 $\mathrm{kcal} / 100 \mathrm{~g}$ respectively. The corresponding values for garlic were $27.7,1.0,2.5,1.5 \mathrm{~g} / 100 \mathrm{gDM}$ and $411.3 \mathrm{kcal} / 100 \mathrm{~g}$. K was the most abundant mineral followed by $\mathrm{Mg}$, $\mathrm{Na}$ and $\mathrm{Ca}$. Among the trace minerals, $\mathrm{Mn}$ was the most abundant and $\mathrm{Zn}$, the least. A similar trend was found in garlic. The mean value for water absorption capacity (WAC) and oil absorption capacity(OAC) in ginger $(410.0,407.3 \%)$ respectively were lower than those of garlic $(580.0,630.9 \%)$ while the foaming stability and emulsion stability(43.7 and $48.0 \%)$ were higher. Mean phytate and phytin-P content in ginger $(27.1 \& 7.6 \mathrm{mg} / \mathrm{g})$ were similar to those of garlic ( $23.7 \& 6.7 \mathrm{mg} / \mathrm{g}$ ) respectively while the polyphenols (as tannic acid equivalent) and oxalate levels in ginger were generally lower than in garlic as indicated by very high $\mathrm{CV}(\%)$ ranging from 139.3 to $118.4 \%$. Diethylether extracted oils from ginger had acid value $(\%)$, free fatty acid(\%), saponification value $(\mathrm{mmKOH} / \mathrm{g})$, peroxide value $(\mathrm{mmKOH} / \mathrm{g})$ and iodine value(Wij's) of 4.1, 2.1, 90.92 .31 and 17.1 respectively. The corresponding values for garlic were $2.8 \%, 1.4 \%, 92.1 \mathrm{mmKOH} / \mathrm{g}$, $5.8 \mathrm{mmKOH} / \mathrm{g}$ and 10.9 Wij's, respectively.The thin layer Gas chromatographic analysis of the seed oils revealed the presence of fatty acids varying from $\mathrm{C}_{2}$ to $\mathrm{C}_{18}$ with concentrations of individual fatty acids varying from 0.30 to $1.6 \%$. Oleic, stearic, palmitic and lauric acids were the principal fatty acids contributing to $1.43,1.5,1.3$ and 1.0\% respectively in ginger while the corresponding values in garlic were 1.5, 1.6, 1.4 and 1.1\%, respectively. Antioxidant potentials measured as total phenol $\mathrm{g} / 100 \mathrm{~g}$, reducing power $\left(\mathrm{OD}_{700}\right)$ and free radical scavenging ability $(\%)$ were higher in ginger $(3.6,1.0,14.4$; respectively than in garlic $(2.9,0.7,13.1)$.
\end{abstract}

Keywords: Nutritive and Oil Characteristics, Functional Properties, Anti-Oxidant Potentials, Ginger and Garlic

\section{Introduction}

Garlic (Allium sativum) and ginger (Zingiber officinale)) are spices which are esoteric food adjuncts that have been in use from human creation. Apart from being used to enhance sensory quality of foods, they are used in perfumery, cosmetics and toiletries. They have long been recognized to possess medicinal properties such as tonic, carminative and antihelminthic (Kempaiah and Srinivasan, 2004).

Garlic is a bulb of lily like plant belonging to the same family as onions. It is commonly used as a flavouring agent and herbal supplement. Garlic is characterized by the remarkable sulphur-containing compound which gives distinctive smell and pungency. Uninjured bulb of garlic contains alliinase one of the major protein components of garlic bulb Shimon et al (2006). The enzyme is a homodimeric glycoprotein and catalyzes the conversion of non-protein sulfur containing amino acid alliin (+S)-ally-Lcysteine sulfoxide) to allicin (diallyl thiosulfinate, the well known biologically active component of freshly crushed garlic), Garlic has been used orally to reduce cholesterol, hardening of the arteries, blood clotting and blood pressure 
(Nwinukadal et al., 2005). Ginger (Zingiber officinate) grows well on a good composite soil with a neutral to alkaline $\mathrm{pH}$ level. The characteristic organoleptic properties of ginger are due to steam volatile oil and non-volatile solvent extractable pungent component. The pleasant aroma of ginger is caused by more than 70 constituents among which is sesquiterpene hydrocarbon while the pungent taste is caused by a number of components namely gingerols, shagoals and zingerone (Encyclopedia of Spices, 2007).

Researches concerning these spices are usually focused on the medicinal values, however, there is paucity of information on the nutrient and the anti-nutrient contents as well as the functional attributes such as water and oil capacity, emulsion capacity and stability, foaming capacity and stability, least gelation ,bulk density and protein solubility. Therefore, the aim of this present study was to characterise these spices and their oils with respect to their nutrient and anti-nutrient contents, functional and antioxidant properties, physiochemical properties and fatty acids composition.

\section{Materials and Methods}

\subsection{Materials}

Raw garlic (Allium sativum) and ginger (Zingiber officinale) were obtained from the local market in Akure, Ondo State, Nigeria.

\subsection{Treatment of Samples}

About $2 \mathrm{~kg}$ of each seed were sun-dried separately, and broken into pieces by pounding and milled with kenwood blender. The milled samples were divided into two portions, one portion was used for the physico-chemical analysis of the whole seed and the other portion for the oil extraction .

\subsection{Chemical and Physico-Chemical Analysis}

Proximate analyses of the samples were carried out in triplicates using the method described by Association of Official Analytical Chemist (AOAC, 1995). Nitrogen was determined by the micro-kjedahl method described by AOAC (1995) and the percentage nitrogen was converted to crude protein by multiplying by 6.25 . The minerals were analysed after dry-ashing at $550^{\circ} \mathrm{C}$ in a Muffle furnace and dissolved in de-ionized water to make standard solutions. Sodium and Potassium were determined by flame photometry while Phosphorus was determined by the Vanado molybdate method (AOAC, 1995). $\mathrm{Mg}$ and $\mathrm{Ca}$ were determined by flame photometry (model 405,corning UK) using standard calibration methods. while $\mathrm{Fe}, \mathrm{Zn}, \mathrm{Cu}$ and $\mathrm{Mn}$ were determined using an atomic absorption spectrophotometer (Perkin Elmer model 403,Norwalk CT,USA) Vogel ( 1982). The gross energy content of the different samples were computed from the \% proximate composition ( $\mathrm{Ng}$ and Wee, 1989) as follows: $\mathrm{GE}(\mathrm{kcal} / 100 \mathrm{~g})=\mathrm{CP} \times 5.7$ - (EE x 9.5) ( NFE x 4.0); where GE, gross energy; CP, crude protein; EE, ethyl extract and NFE, nitrogen-free extract.

\subsection{Determination of Functional Properties}

The water absorption capacity (WAC) and fat emulsion stability (FES) were determined by the procedure of Beuchat (1977). The fat absorption capacity (FAC) was determined as described by Sosulki (1962) and the lowest gelation capacity (LGC), foaming capacity (FC) and foaming stability (FS) were determined using a standard technique described by Coffman and Garcia (1977). The variation of protein solubility with changing $\mathrm{pH}$ was determined as described by Oshodi and Aletor (1993).

\subsection{Quantification of Anti-Nutrients}

Tannins: Finely milled and sieved sample was prepared by dissolving $200 \mathrm{mg}$ in $10 \mathrm{~mL}$ of $70 \%$ aqueous acetone extracted for $2 \mathrm{hrs}$. at $30^{\circ} \mathrm{C}$ in a water bath using Gallenkamp orbital shaker at 120 r.p.m. and filtered. The total polyphenol (as tannic equivalent) was determined in $0.05 \mathrm{~cm}^{3}$ aliquot in test tube by the addition of $0.5 \mathrm{~mL}$ of the Folin Ciocalteau reagent (Sigma St Lous MD, USA) and the $2.5 \mathrm{~cm}^{3}$ sodium carbonate solution. The tubes were vortexed and the absorbance recorded at $725 \mathrm{~nm}$ after 40 minutes as described by Makkar and Goodchild (1994), the amount of total phenols (as tannic equivalent) was calculated from the standard curve, calibrated as earlier obtained with pure tannic acid.

Phytin: For the quantification of phytin, $8 \mathrm{~g}$ each of finely ground samples were soaked in $200 \mathrm{~mL}$ of $2 \% \mathrm{HCl}$ and allowed to stand for $3 \mathrm{hrs}$. The extracts were thereafter filtered through two layers of hardened filter paper and 50 $\mathrm{cm}^{3}$ aliquot of the filtrate was pippetted into $400 \mathrm{~cm}^{3}$ capacity beakers before the addition of $10 \mathrm{~cm}^{3} 0.3 \%$ ammonium thiocyanate solution as an indicator and $107 \mathrm{~cm}^{3}$ of distilled water to obtain the proper acidity ( $\mathrm{pH} \mathrm{4.5),} \mathrm{the}$ solution was then titrated with a standard iron chloride $\left(\mathrm{FeCL}_{3}\right)$ solution containing $0.00195 \mathrm{~g}(1.95 \mathrm{mg}) \mathrm{Fe} / \mathrm{cm}^{3}$ until a brownish yellow colour persisted for 5minutes.Phytinphosphorus was determined and phytin content was calculated by multiplying the value of phytin-phosphorus by 3.55 (Young and Greaves, 1940). Each milligram of iron is equivalent to $1.19 \mathrm{mg}$ phytin-phosphorus.

Determination of Oxalate content: To $1 \mathrm{~g}$ of the powder sample, $75 \mathrm{~cm}^{3}$ of $1.5 \mathrm{M} \mathrm{H}_{2} \mathrm{SO} 4$ was added. The solution was carefully shaken on a mechanical shaker for $1 \mathrm{hr}$ and then filtered using Whattman No.1 filter paper. The filtrate $\left(25 \mathrm{~cm}^{3}\right)$ was then collected and titrated against $0.1 \mathrm{M} \mathrm{KMn0} \mathrm{K}_{4}$ solution till a faint pink colour that persisted for 30secs appeared..

$1 \mathrm{~cm}^{3}$ of $0.1 \mathrm{M} \mathrm{KMnO}_{4}=0.00450 \mathrm{~g}$ oxalic acid (Day and Underwood,1986)

\subsection{Aqueous Extract Preparation}

The aqueous extract of the garlic and ginger were prepared using procedure descried by Oboh et al. (2007). Briefly, about $2 \mathrm{~g}$ of each milled spice was soaked in $40 \mathrm{~mL}$ deionised water for $5 \mathrm{~min}$. Thereafter, the mixtures were centrifuged at 2000 r.p.m. for $10 \mathrm{~min}$. The supernatant was used for the determination of total phenolic content, reducing 
power and radical scavenging ability.

\subsection{Total Phenol Determination}

The total phenol was determined using Folin-Ciocalteu method of Jagadish et al.(2009) with slight modification.The methanolic extract $(0.5 \mathrm{~mL})$ was added to a $25 \mathrm{~mL}$ volumetric flask filled with $10 \mathrm{~mL}$ deionised distilled water and $2.5 \mathrm{~mL}$ of $2 \% \mathrm{Na}_{2} \mathrm{CO}_{3}$ solution was added, with mixing . The solution was diluted to the volume $(25 \mathrm{~mL})$ with deionised distilled water and then allowed to stand for $90 \mathrm{~min}$, and the absorbance was measured at $780 \mathrm{~nm}$ versus the prepared blank. Quercetin was used as standard for the calibration curve. Total phenolic contents were calculated as mg quercetin $\mathrm{g}^{-1}$ dry weight of sample

\subsection{Determination of Reducing Capacity}

The reducing property of free and bound phenolics were determined by assessing the ability of the spices to reduce $\mathrm{FeCL}_{3}$ solution as described by Pulido et al. (2000). Briefly, appropriate dilutions of the extracts $(2.5 \mathrm{~mL})$ were mixed with $2.5 \mathrm{~mL}$ of $200 \mathrm{~mL}$ sodium phosphate buffer $(\mathrm{pH} 6.6)$ and $2.5 \mathrm{~mL}$ of $1 \%$ potassium ferricyanide. The mixture was incubated at $50^{\circ} \mathrm{C}$ for $20 \mathrm{~min}$. Thereafter, $2.5 \mathrm{~mL}$ of $10 \%$ trichloroacetic acid was added before the sample was centrifuged at 650 r.p.m. for $10 \mathrm{~min}$. $5 \mathrm{~mL}$ of the resulting supernatant was mixed with equal volume of water and $1 \mathrm{~mL}$ of $0.1 \%$ ferric chloride. The absorbance was taken at $700 \mathrm{~nm}$.

\subsection{Determination of Free Radical Scavenging Ability}

The hydrogen atom or electron donating abilities of the corresponding extracts and some pure compounds were measured from bleaching of the purple-coloured methanolic solution of 2,2-diphenyl-1-picrylhydrazyl (DPPH) as shown in the equation below.

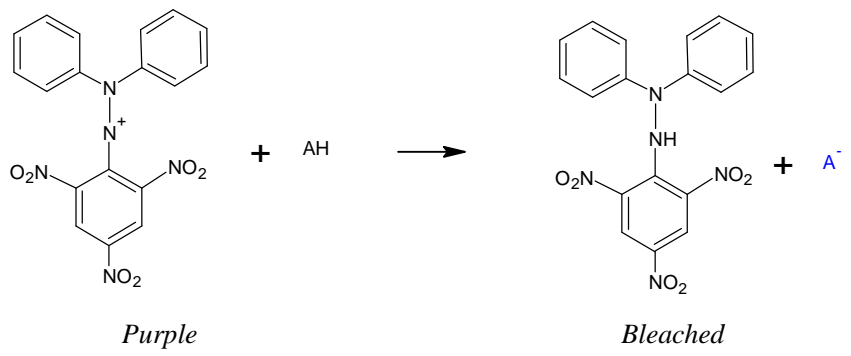

One $\mathrm{mL}$ of various concentrations of the extracts in methanol was added to $4 \mathrm{~mL}$ of $0.1 \mathrm{mmol} \mathrm{L}^{-1}$ methanolic solution of DPPH and $200 \mu \mathrm{L}$ of deionised distilled water $\left(\mathrm{ddH}_{2} 0\right)$. After $30 \mathrm{~min}$. of incubation in the dark at room temperature ,the absorbance was read at $517 \mathrm{~nm}$ against the prepared blank. Inhibition of free radicals by DPPH in percent $(\%)$ was calculated using this formula:

$$
I(\%)=\left[\frac{A_{\text {blank }}-A_{\text {sample }}}{A_{\text {blank }}}\right] \times 100
$$

Where the $A_{\text {blank }}$ is the absorbance of the control reaction (containing all reagents except the test compound) and $\mathrm{A}_{\text {sample }}$ is the adsorbance of the test compound

\subsection{Extraction of Oil from the Milled}

About $3 \mathrm{~g}$ of each milled spice was taken and the oil extracted for 6 hours with diethyl ether in a soxhlet extractor. Thereafter, the solvent was evaporated under reduced pressure (AOAC, 1995).

\subsection{Analysis of the Seed Oils}

The physico-chemical properties of the crude oil extracted viz: the acid value, saponification value, peroxide value, iodine value and free fatty acid (as oleic acid) were determined (AOAC, 1995).

\subsection{Gas Chromatography (GC) Analysis of Fatty Acids}

The fatty acid profile of oil $(5 \mathrm{~mL})$ was determined after trans-esterification of the oil triacylglycerols (TG) by $14 \%$ $\mathrm{BF}_{3} / \mathrm{MeOH}$ (EEC,2003).The resulting FAME were separated on a $50 \mathrm{~m} \times 0.25 \mathrm{~mm}$ internal diameter BPX 70 capillary column, coated with a $0.25 \mu \mathrm{m}$ thickness of cyanopropyl silicone provided by SGE (Melbourne, Australia), using an Agilent Tech. (formerly Hewlett Packard,HP) HP-6890 gas chromatograph (Avondale, PA, USA), equipped with MSD6890 mass ionization detector. HP, MS Chemstation software was used for quantification and identification of peaks. Peak identifies were verified by refrence to a mass spectra library. The analytical conditions were as follows: carrier gas He, flow/rate $1.0 \mathrm{ML} \mathrm{min}^{-1}$, inlet $230^{\circ} \mathrm{C}$, oven from 150 to $260^{\circ} \mathrm{C}$ in $40 \mathrm{~min}$, mass dectector transfer line $280^{\circ} \mathrm{C}$. The injector volume was $1 \mu \mathrm{L}$

\subsection{Data Analysis}

Values for all parameters measured between the Seeds and their oils were assigned a coefficient of variation (CV) as described (Snedocor and Cochray, 1973).

\subsection{Results and Discussion}

The proximate composition and gross energy of the ginger and garlic are presented in Table 1. The values for the crude fibre (CF), ethyl extract (EE), ash and nitrogen free extract (NFE) $(6.2,11.0,9.0,59.1 \mathrm{~g} / 100 \mathrm{~g} \mathrm{DM}$, respectively) in the ginger were higher than those in garlic (1.0, 2.5, 1.5 and 57.8 $\mathrm{g} / 100 \mathrm{~g} \mathrm{DM}$, respectively), while crude protein and energy in garlic (27.4 g/100 g DM; $411.3 \mathrm{kcal} / 100 \mathrm{~g} \mathrm{DM}$ respectively) were higher in ginger $(7.9 \mathrm{~g} / 100 \mathrm{~g} \mathrm{DM}$ and $385.6 \mathrm{kcal} / 100 \mathrm{~g}$ DM). The result of proximate composition compare well and even higher than those determined in other food condiments such as fermented Iru, under-utilized legumes and Struchium spaganophora leaves use in food preparation (Oboh, 2006; Aletor et al,2009). The result on crude protein especially in garlic suggests that they can be used to enhance low-protein traditional African foods such as maize gruel and other cassava based foods.

The mineral content of the ginger and garlic are shown in 
Table 2. Among the major minerals $\mathrm{Na}, \mathrm{Mg}$ and $\mathrm{Ca}$ in ginger had $1.5,397.6$ and $116.1 \mathrm{mg} / 100 \mathrm{~g}$ respectively while similar trend of $4.2,355.6$, and $107.0 \mathrm{mg} / 100 \mathrm{~g}$ respectively was found in garlic. Mineral values of $\mathrm{K}$ and $\mathrm{P}$ were higher in garlic 90.0, 214.0mg/100g than in ginger 32.0, 151.4 $\mathrm{mg} / 100 \mathrm{~g}$ respectively. Marked variabilities were recorded in their trace minerals of $\mathrm{Fe}, \mathrm{Cu}$ and $\mathrm{Mn}$ as indicated by the coefficient of variation (CV) of $74.1,42.5$ and $90.1 \%$ respectively. The minerals levels in ginger and garlic seem adequately comparable since they fall within the usual range of most plant and animal proteins Fasuyi (2007).

Data on the functional properties with regard to water absorption capacity (WAC), oil absorption capacity (OAC), foaming capacity (FC), foaming stability (FS), emulsion capacity (EC), emulsion stability (ES), least gelation (LG) and bulk density (BD) are presented in Table 3. The garlic showed higher WAC, OAC, FC, EC, LGC and BD (580.0, $630.9,2.0,35.6,8.0,0.3$ respectively), while ginger showed higher FS and ES (43.7 and 48.0\% respectively). The garlic and ginger showed higher variation in FS and ES as indicated by high coefficient of variation (CV) of 60.4 and $64.2 \%$ respectively. This result compared well with those reported for fermented Iru and soyabean condiment (Aletor et al., 2009). The results on WAC and OAC were higher than those reported by Oshodi et al. (1999) on benniseed. The results on WAC and OAC indicate their use in viscous foods such as soups and gravies while their results on OAC suggest garlic, a better flavour retainer when compared to ginger. The result on foaming capacity and stability are generally low when compared with leaf protein concentrate (LPC) and fish meal reported by (Aletor, 2010). The foaming capacity is important since the success of whipping agents depend on their ability to maintain whip as long as possible.

The values of emulsion capacity and stability of the ginger and garlic are similar and compared well with those reported for LPC and fish meal (Aletor, 2010). This suggests that the ginger and garlic can be used as additives for the stabilization of emulsions in the production of soups and cakes. The least gelation showed that garlic had higher values than ginger but the values compares well with those reported for unfermented and fermented locust and soya bean seeds (Aletor et al., 2009). These results showed that garlic may form a better gel than those of ginger. The ability of proteins to form gels, provide a structural matrix for holding water and flavours which are useful food ingredients. The spices showed variable solubilities, ( Fig 1) with varying $\mathrm{pH}$ ranges in both acidic and basic regions which could be useful in industrial applications.

The levels of antinutrients Tannin, Phytate and Phytin-P, and oxalate are shown in Table 4 . The tannin content ranged from $0.1 \mathrm{mg} / \mathrm{g}$ in ginger to $2.6 \mathrm{mg} / \mathrm{g}$ in garlic. These values compare well with the tannin content for cassava products (Oboh and Akindahunsi, 2003) and three varieties of mushrooms (Aletor and Alabi, 2010). The tannin level in these spices are considered safe with regard to tannin poisoning because the levels reported in this study are far below critical value 7.3 - $9.0 \mathrm{mg} / \mathrm{g}$ (Aletor, 1993).
The phytate content of the spices ranged from $23.7 \mathrm{mg} / \mathrm{g}$ in garlic to $27.0 \mathrm{mg} / \mathrm{g}$ in ginger while phytin-P ranged from 6.7 $\mathrm{mg} / \mathrm{g}$ in garlic to $7.6 \mathrm{mg} / \mathrm{g}$ in ginger. These values were lower than those reported by (Oboh et al., 2005) for condiments produced from pigeon pea $187.8 \mathrm{mg} / 100 \mathrm{~g}$ and soyabeans $921.2 \mathrm{mg} / 100 \mathrm{~g}$. Phytic acid though considered an antinutritional factor but, it is of particular importance in monogastric animals (including man )who lack phytase ,an enzyme that break down phytin to release phosphorus for metabolism. Oxalate content varied from $0.7 \mathrm{mg} / \mathrm{g}$ in ginger to $8.2 \mathrm{mg} / \mathrm{g}$ in garlic. These values were lower than the oxalate content in varieties of muchrooms reported by Aletor and Alabi, 2012). Reviews by Fasset (1966) indicate very little danger associated with the ingestion of oxalatecontaining plants. Studies by Aletor (1995) suggest contrary views, especially with respect to magnesium, the metabolism of which is reported to be impaired by oxalic acid.

The physico-chemical properties of the oils of ginger and garlic (Table 5) showed acid value and free fatty (as oleic \%) saponification, peroxide value and iodine value for ginger (4.1 mg/OH/g, 2.9 (as oleic acid) $90.9 \mathrm{mg} / \mathrm{OH} / \mathrm{g}, 2.3 \mathrm{meq} / \mathrm{kg}$ and $17.1 \mathrm{Wijs}$ respectively) and the corresponding garlic had (2.8 mg/OH/g, 1.4 (as oleic acid) $92.1 \mathrm{mg} / \mathrm{OH} / \mathrm{g}, 5.8 \mathrm{meq} / \mathrm{kg}$ and 10.9 Wijs respectively). Ginger had higher acid value, free fatty acid and iodine value than garlic while high coefficient of variation (CV) of $60.9 \%$ was observed in peroxide value in garlic. Results on their acid and free fatty acid values expressed as oleic acid indicate that no particular problem would be encountered upon refining them in order to get a bland oil,the low peroxide value indicates the absence of rancidity in the oil samples while the low iodine value reflects low proportion of unsaturated fatty acid glycerides. The values obtained from the physico-chemical properties of the oils were still below the recommended standards (Codex Alimentarius Commission (1970) and compared well with those reported by Aletor et al. (2007) on the whole and rejected cashew nut oils.

Fatty acid profile Table (6) in ginger consisted of 0.5, 1.4, $1.5,1.3,1.0,0.4,0.3,0.3$ and $0.4 \%$ myristic, oleic, stearic, palmitic, lauric, linolenic, linoleic, palmitoleic and arachinic acid respectively while corresponding garlic $(0.5,1.5,1.6$, $1.4,1.1,0.3,0.3,0.4$ and $0.3 \%$ respectively. The total saturated and unsaturated fatty acids in ginger $4.9,2.1 \%$ respectively and garlic 5.3, 2.2\% respectively. The distribution percentages of fatty acid component in ginger and garlic had some similarities and differences, when compared with those of Rosa canina, Rosa villosa and Rosa dumalis seed oils (Ozman, 2002). This situation could be attributed to different climate, soil, ecological and environmental conditions.

Antioxidant parameter table (7) showed that ginger had higher phenol, reducing power and free radical scavenging ability $3.6 \mathrm{~g} / 100 \mathrm{~g}, 1.0 / \mathrm{OD}_{700} ; 14.2 \%$ respectively than garlic ( $2.9 \mathrm{~g} / 100 \mathrm{~g}, 0.7 / \mathrm{OD}_{700}$ and $13.1 \%$ respectively). The values compare well with those of polyphenol extracts from some species of red pepper (Oboh\& Rocha, 2006) but lower than those reported by Oboh (2006) on the S. sparganophora leaf. 
Phenolic phytochemicals inhibit auto-oxidation of unsaturated lipids, thus preventing the formation of oxidized low-density lipoprotein, which is considered to induce cardiovascular disease (Amic et al., 2003). The reducing power of the seeds clearly indicate their ability to reduce $\mathrm{Fe}(\mathrm{III})$ to $\mathrm{Fe}(\mathrm{II})$. The ability of the extracts to scavenge the stable DPPH free radical is expressed as:

$(\mathrm{DPPH}-)+(\mathrm{AH}) \mathrm{n} \quad \mathrm{DPPH}-\mathrm{H}+(\mathrm{A}-) \mathrm{n}$

The result of the total phenol content, free radical scavenging activity and reducing property agree with the report (Oboh, 2006) that plant foods have strong antioxidant activity.

Table 1. Proximate Composition g/100gDM and gross energy kcal/100g of Ginger and Garlic $(n=3)$.

\begin{tabular}{llllllll}
\hline & Dry Matter & Crude Protein & Crude Fibre & Ether Extract & Ash & NFE & Gross Energy $(\mathbf{k c a l} / \mathbf{1 0 0 g})$ \\
\hline Ginger & $92.9 \pm 0.6$ & $7.8 \pm 0.4$ & $6.2 \pm 0.4$ & $11.0 \pm 0.3$ & $9.0 \pm 0.5$ & $59,1 \pm 3$ & $385.6 \pm 0.7$ \\
Garlic & $90.3 \pm 0.3$ & $27.4 \pm 0.5$ & $1.0 \pm 0.6$ & $2.5 \pm 0.2$ & $1.5 \pm 0.6$ & $57.8 \pm 0.5$ & $411.3 \pm 0.5$ \\
Mean & 91.6 & 17.7 & 3.6 & 6.8 & 5.3 & 54.5 & 398.5 \\
S.D. & 1.9 & 13.9 & 3.7 & 6.0 & 5.3 & 0.9 & 18.2 \\
CV \% & 2.0 & 77.6 & 102.2 & 88.5 & 101.0 & 1.7 & 4.6 \\
\hline
\end{tabular}

S.D. Standard Deviation, C. V, Coefficient of Variation; NFE, Nitrogen Free Extracts

Table 2. Nutritionally valuable minerals $m g / 100 g$ of ginger and garlic $(n=3)$.

\begin{tabular}{llllllllll}
\hline & $\mathbf{N a}$ & $\mathbf{K}$ & $\mathbf{M g}$ & $\mathbf{C a}$ & $\mathbf{F e}$ & $\mathbf{Z n}$ & $\mathbf{C u}$ & $\mathbf{P}$ & $\mathbf{M n}$ \\
\hline Ginger & $1.5 \pm 0.4$ & $32.00 \pm 0.3$ & $379.6 \pm 0.2$ & $116.1 \pm 0.7$ & $4.4 \pm 0.3$ & $1.3 \pm 0.8$ & $2.6 \pm 0.3$ & $151.4 \pm 0.4$ & $6.5 \pm 0.6$ \\
Garlic & $4.9 \pm 0.3$ & $90.0 \pm 0.5$ & $355.6 \pm 0.6$ & $107.0 \pm 0.4$ & $1.4 \pm 0.6$ & $1.2 \pm 0.9$ & $1.4 \pm 0.6$ & $214.0 \pm 0.7$ & $1.4 \pm 0.5$ \\
Mean & 3.2 & 61.0 & 367.6 & 115.5 & 2.9 & 1.2 & 2.0 & 182.7 & 3.9 \\
S.D. & 2.4 & 41.0 & 17.0 & 6.5 & 2.2 & 0.1 & 0.9 & 44.3 & 3.6 \\
CV \% & 75.0 & 67.2 & 4.6 & 0.6 & 74.1 & 7.3 & 43.0 & 24.2 & 92.3 \\
\hline
\end{tabular}

S.D. Standard Deviation, C.V. Coefficient of Variation;

Table 3. Functional properties (\%) of ginger and garlic $(n=3)$.

\begin{tabular}{lllllllll}
\hline & WAC & OAC & FC & FS at 30mis & EC & Es at 15mis & LGC & BD \\
\hline Ginger & $41.0 \pm 0.5$ & $407.3 \pm 0.1$ & $1.5 \pm 0.6$ & $43.7 \pm 1.0$ & $22.5 \pm 0.9$ & $48.0 \pm 0.5$ & $6.0 \pm 0.2$ & $0.3 \pm 0.1$ \\
Garlic & $580.0 \pm 0.3$ & $630.9 \pm 0.6$ & $2.0 \pm 0.5$ & $17.5 \pm 0.9$ & $35.6 \pm 0.4$ & $18.0 \pm 0.6$ & $8.0 \pm 0.4$ & $0.3 \pm 0.1$ \\
Mean & 495.0 & 519.1 & 1.8 & 30.6 & 29.0 & 33.0 & 7.0 & 0.0 \\
S.D. & 120.2 & 158.1 & 0.4 & 18.5 & 9.2 & 21.2 & 1.4 & 0.0 \\
CV \% & 24.2 & 30.5 & 20.0 & 60.4 & 31.7 & 64.2 & 20.1 & 33.3 \\
\hline
\end{tabular}

WAC, Water absorption capacity; OAC, oil absorption capacity; FC, Foaming capacity; FS, Foaming stability; EC, Emulsion capacity; ES, Emulsion stability; LGC, Least gelation capacity; BD, Bulk density; SD, Standard deviation; CV, Coefficient of variation.

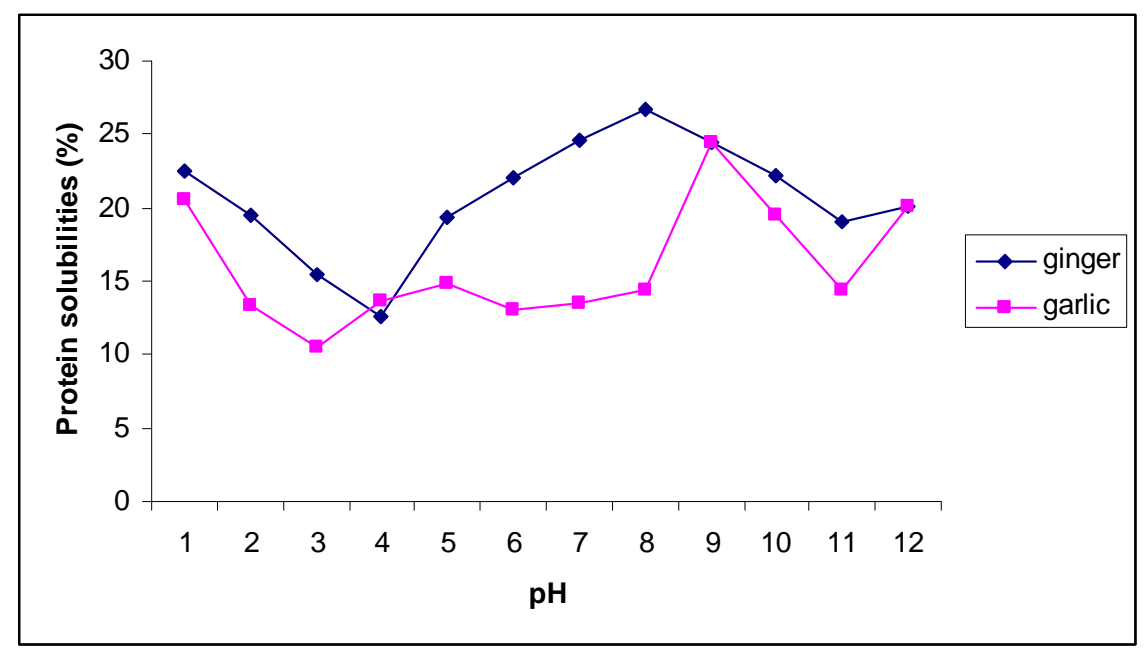

Fig. 1. Protein solubility of ginger and garlic as a function of $\mathrm{pH}$. 
Table 4. Tannin, phytin, Phytin. $P$ and Oxalate content $\mathrm{mg} / \mathrm{g}$ of ginger and garlic $(n=3)$.

\begin{tabular}{lllll}
\hline & Tannin & Phytic acid & Phytin. P & Oxalate \\
\hline Ginger & $0.1 \pm 0.4$ & $27.0 \pm 0.2$ & $7.6 \pm 0.6$ & $0.7 \pm 0.7$ \\
Garlic & $2.6 \pm 0.5$ & $23.7 \pm 0.3$ & $6.7 \pm 0.6$ & $8.2 \pm 0.5$ \\
Mean & 1.35 & 25.3 & 7.1 & 4.5 \\
S.D. & 1.76 & 2.3 & 0.7 & 5.3 \\
CV \% & 130.4 & 9.2 & 9.2 & 118.4 \\
\hline
\end{tabular}

S.D. Standard Deviation, C.V. Coefficient of Variation;
Table 5. Physico-chemical properties of ginger and garlic oils.

\begin{tabular}{llllll}
\hline & Ginger & Garlic & Mean & S.D. & CV \% \\
\hline $\begin{array}{l}\text { Acid value } \mathrm{mg} / \mathrm{OH} / \mathrm{g} \\
\begin{array}{l}\text { Free fatty acid (as } \\
\text { oleic acid) }\end{array}\end{array}$ & $4.1 \pm 0.5$ & $2.8 \pm 0.3$ & 3.5 & 0.9 & 27.0 \\
$\begin{array}{l}\text { Saponification value } \\
\mathrm{mg} / \mathrm{KOH} / \mathrm{g}\end{array}$ & $90.9 \pm 0.5$ & $92.1 \pm 0.9$ & 91.5 & 0.8 & 0.9 \\
$\begin{array}{l}\text { Peroxide value } \mathrm{mcg} / \mathrm{kg} \\
\text { Iodine value (Wij's) }\end{array}$ & $2.3 \pm 0.3$ & $5.8 \pm 0.6$ & 4.1 & 2.5 & 60.9 \\
\hline
\end{tabular}

S.D. Standard Deviation, C.V. Coefficient of Variation;

Table 6. Fatty acid profile (\%) of ginger and garlic oils.

\begin{tabular}{|c|c|c|c|c|c|}
\hline & Ginger & Garlic & Mean & S.D. & $\mathrm{CV} \%$ \\
\hline Lauric acid $\mathrm{CH}_{3}\left(\mathrm{CH}_{3}\right)_{10} \mathrm{COOH}$ & 1.0 & 1.1 & 1.1 & 0.1 & 9.0 \\
\hline Myristic acid $\mathrm{CH}_{3}\left(\mathrm{CH}_{3}\right)_{12} \mathrm{COOH}$ & 0.5 & 0.5 & 0.5 & 0.0 & 2.1 \\
\hline Palmjitic acid $\mathrm{CH}_{3}\left(\mathrm{CH}_{3}\right)_{14} \mathrm{COOH}$ & 1.3 & 1.4 & 1.4 & 0.1 & 7.1 \\
\hline Stearic acid $\mathrm{CH}_{3}\left(\mathrm{CH}_{3}\right)_{16} \mathrm{COOH}$ & 1.5 & 1.6 & 1.6 & 0.1 & 6.3 \\
\hline Palmitoleic acid $\mathrm{CH}_{3}\left(\mathrm{CH}_{2}\right)_{5} \mathrm{CH}=\mathrm{CH}\left(\mathrm{CH}_{3}\right)_{7} \mathrm{COOH}$ & 0.3 & 0.4 & 0.3 & 0.0 & 0.0 \\
\hline Oleic acid $\mathrm{CH}_{3}\left(\mathrm{CH}_{2}\right)_{5} \mathrm{CH}=\mathrm{CH}\left(\mathrm{CH}_{3}\right)_{7} \mathrm{COOH}$ & 1.4 & 1.5 & 1.5 & 0.1 & 6.7 \\
\hline Linoleic $\mathrm{CH}_{3}\left(\mathrm{CH}_{2}\right)_{4} \mathrm{CH}=\mathrm{CH} \mathrm{CH}{ }_{3} \mathrm{CH}=\mathrm{CH}\left(\mathrm{CH}_{2}\right)_{7} \mathrm{COOH}$ & 0.4 & 0.3 & 0.3 & 0.0 & 0.0 \\
\hline Linolenic $\mathrm{CH}_{3} \mathrm{CH}_{2} \mathrm{CH}=\mathrm{CH} \mathrm{CH}{ }_{2} \mathrm{CH}=\mathrm{CH} \mathrm{CH}_{3} \mathrm{CH}=\mathrm{CH}\left(\mathrm{CH}_{2}\right)_{7} \mathrm{COOH}$ & 0.3 & 0.3 & 0.3 & 0.0 & 0.0 \\
\hline Arachidonic $\mathrm{C}_{25} \mathrm{H}_{32} \mathrm{O}_{2}$ & 0.4 & 0.3 & 0.4 & 0.0 & 0.0 \\
\hline$\Sigma$ & 7.0 & 7.4 & 7.2 & 0.3 & 4.2 \\
\hline$\Sigma$ Saturated & 4.9 & 5.3 & 5.1 & 0.2 & 3.9 \\
\hline$\Sigma$ unsaturated & 2.1 & 2.2 & 2.1 & 0.1 & 4.8 \\
\hline
\end{tabular}

S.D. Standard Deviation, C.V. Coefficient of Variation;

Table 7. Antioxidant properties in ginger and garlic extracts $(n=3)$.

\begin{tabular}{llllll}
\hline Antioxidant parameter & Ginger & Garlic & Mean & S.D. & CV \% \\
\hline $\begin{array}{l}\text { Total phenol (mg } \\
\text { quercetin/g) }\end{array}$ & 360 & 290 & 3.1 & 0.5 & 16.1 \\
$\begin{array}{l}\text { Reducing power (OD700) } \\
\begin{array}{l}\text { Free radical scavenging } \\
\text { ability (\%) }\end{array}\end{array}$ & 1.0 & 0.7 & 0.9 & 0.2 & 22.2 \\
\hline
\end{tabular}

S.D. Standard Deviation, C.V. Coefficient of Variation;

\section{Conclusion}

From the results of this study it could therefore be inferred that ginger and garlic are promising nutritionally and medicinally because of their high nutrient content, low antinutrient and moderate antioxidant potentials. Furthermore, the seed oils can be exploited as sources of edible and industrial oils and lastly, this study has shown that they are relatively rich in saturated and unsaturated fatty acids.

\section{References}

[1] Prof.Aletor V. Ayobore Allelochemicals in plant food and feeding stuff (1): Nutritional biochemical and physiopathological aspects in animal production. Journal of Veterinary and Human Toxicology-1993 35 (1): 57-67.

[2] Prof.Aletor, V.Ayobore Composition studies on edible tropical specie of mushroom Journal of Food Chemistry-1995 53: 375-379.
[3] Dr.Aletor, Oluwatoyin, Owoeye, F.Beatrice and Prof.Aletor, V.Ayobore Effect of fermentation on the physic -chemical composition and multi-enzyme in vitro protein digestibility of Africa locust bean (Parkia biglobosa) and soyabean (Glycine max) seeds. Journal of Chemical Society of Nigeria (CSN)200734 (2): 126-133.

[4] Dr.Aletor, Oluwatoyin, Prof.Agbede, J.Olusola, Adeyeye, S.Adebowale and Prof.Aletor, V.Ayobore Chemical and Physico-Chemical characterization of the flours and oils from whole and rejected cashew-nut cultivated in south west Nigeria. Pakistan Journal of Nutrition-2007 6(1): 89-93.

[5] Dr.Aletor, Oluwatoyin, Alabi O.Olutayo Physico-chemical nutrient and anti-nutrient composition of three edible species of Mushroom. Journal of Science, Research and Management-2012 8 (1):7-13.

[6] Dr.Aletor, Oluwatoyin Comparative, nutritive and physicchemical evaluation of cassava (manihoto esculenta) leaf protein concentrate and fishmeal. Journal of Food Agriculture and Enviroment-2010 8(2): 39 - 43.

[7] Amic D.,Davidovic, Beslo,D and Trinajstic,N. Structure radical scavenging activity relationship of flavonoids. Croatia Chemical Acta-2003 76 (1), 55-61

[8] AOAC Official method of Analysis $15^{\text {th }}$ Edu. Association of official Analytical Chemist-1995 Washington DC.

[9] Prof.Beuchat,R.Larry Functional and electrophoretic characterization of succinylated peanut flour protein. Journal of Agriculture and Food Chemistry-1977 25: 258-261.

[10] Codex Alimentarius Commission Recommended standard for edible fats and oils. A report by Joint FAO/WHO Programme1970 Rome. 
[11] Coffin, C.W. and Garcia, V.V. Functional properties and amino acid content of a protein isolate from mungbean flour. Journal of Food Technology-1977 12: 473-484.

[12] Day, R.A. and Underwood, A.L., Quantitative analysis $5^{\text {th }}$ 1986 edition prentice-Hall

[13] Encyclopedia of Chemical Technology- . Vol 10, $3^{\text {rd }}$ (Eds) 1980. pp 477 - 480. New York: John Wiley and Sons.

[14] Fasset, D.W.Oxalates in toxicants occurring naturally in Foods. National Academy of Science Research Council-1966 18: 2022. Washington DC.

[15] Dr.Fasuyi. A Oludare .2007 .Bio-nutrient evaluations of three tropical leaf vegetables (Telfaria occidentalis, Amaranthus cruentis and Talium triangulae) as a sole dietary protein sources in rat assay.Journal Food Chemistry-2007 103: 757765

[16] Jagadish L.K, Krishnan V.V; Shenbhagaraman R; Kaviyarasan VComparative study on the nantioxidant, anticancer and antimicrobial property of Agaricus bisporus imbach before and after boiling. African Journal of Biotechnol-2009 8, 654661.

[17] Kempaiah, R.K, Srinivasan, K. Beneficial influence of dietary curcumin, capsaicin and garlic on erythrocyte integrity in high fat fed rats. Journal of Nutrition and Biochemistry-2004 56 (2): $150-157$.

[18] Makkar, H.P. S and Goodchild, A.V. Quantification of tannins. A laboratory manual International centre for Agric. Research in the Dry Areas ICARDA-1994 pp1-25 Aleppo, Syria.

[19] Nwinuka, N.M., Ibeh, G.O and Ekeke, GProximate composition and levels of some toxicants in four commonly consumed spices. Journal of Applied Science and Enviromental Management-2005 25 (9) : 150-155.

[20] Prof.Ng, W.Keong and Dr. Wee, Kok L. The nutritive value of cassava leaf meal in pelleted feed for Nile Tilapia. Aquaculture-1989 83: 45-48.

[21] Prof. Oboh, Ganiyu, Prof. Akindahunsi, A.A. Biochemical changes in cassava products (flour and garri) subjected to saccharomyces cervisae solid media fermentation. Journal of Food Chem-2003 82: 599-602.

[22] Prof. Oboh, Ganiyu . Nutrient and anti-nutrient composition of condiments produced from some fermented underutilized legumes. Journal of Food Biochemistry-2006 30: 479-488.
[23] Prof. Oboh Ganiyu, Rocha, J.T.B. 2007.Polyphenols in red pepper [Capsicum annuum var. aviculare (Tepin) and their protective effect on some anti-oxidants induced lipid peroxidation in brain and liver .European Food Resource Technology-2007 225(2):239-247.

[24] Prof.Oshodi A. Aladesanmi, Prof. Aletor V. Ayobore. Functional properties of haemagglutinine (Lectins) extracted from three edible varieties of lima beans (phaseolus). International Journal of Food Science and Nutrition1993 44: 133-136.

[25] Prof.Oshodi A. Aladesanmi, Dr. Ogungbenle, H.N. and Prof.Oladimeji, M. O. Chemical composition, nutritionally valuable minerals and functional properties of beniseed (Sesamum radiatum), pearl millet (Pennisetum typhoides) and quionoa (Chenopodium quionoa) of flours. International Journal of Food Science and Nutrition-1999 50: 325-331

[26] Prof. Ozcan, Mutlu Nutrient composition of rose (Rosa caninal) Seed and oils. Journal of Medicinal Foods-2002 5(3): 137-140.

[27] Pulido, R., Bravo, E.R and Saura-Calixto, F. Anti-oxidant activity of dietary polyphenols as determined by a modified ferric reducing /antioxidant power assay. Journal of Agriculture and Food Chemistry-2000 48:137-143.

[28] Shimon, L J., Rabinkov, A Shin,.,. Miron,T., Mirelman,D., Wilchek,M and Frolow, F. . Two structures of alliinase from Alliium sativum L-apo form and ternary complex with aminoacrylate reaction intermediate covalently bound to PLP co-factor.Journal of Molecular Biology-2007 366(2): 611-625.

[29] Snede W.George,Cochran,G.WilliamStatistical method. $\left(6^{\text {th }}\right.$ Eds) 1973 IOWA State University Press. IOWA.

[30] Prof.SosulkoW.Fleming.The centrifuge method of determining flour absorption in hard red spring wheat. Cereal Chemistry-1962 39: 344-350.

[31] Ursini F. Mairino, M., Morazono, P., Roveri, G.,. A novel antioxidants (ldb 1031) affecting molecula mechanisms of cellular activation. Free rad. Bio.\&Med- 1994 16:547-553.

[32] Pof.Vogel, AlrfedT. Quantitative inorganic analysis-1962 pp 802 - 899. London, Longman.

[33] Prof. Young, M. Silas, Dr. Greaves S. Jimmy Influence of variety and treatment of phytin contents of Wheat. Food Resource-1940 5 (1): 103-105. 